Journal of Management and Business Aplication

\title{
FLUCTUATION OF INFLATION VALUE AND BI RATE AGAINST VOLATILITY OF STOCK PRICE IN PT. UNILEVER INDONESIA TbK
}

\author{
Nely Supeni ${ }^{1}$ \\ Helmi Agus Salim ${ }^{2}$ \\ Higher Education of Economic Mandala \\ Email: nely@stie-mandala.ac.id
}

\begin{abstract}
PT. Unilever Indonesia Tbk is one of the companies in the Consumer Goods Industry sector on the Indonesia Stock Exchange (BEI) with the highest share value throughout 2018. The purpose of this study is 1) To partially determine the effect of inflation and the BI Rate on Stock Price Volatility at PT. Unilever Indonesia Tbk, 2) To find out the effect of simultaneous Inflation and BI Rate on Stock Price Volatility at PT. Unilever Indonesia Tbk. This type of research is quantitative research with secondary data type then the analysis used is Multiple Linear Regression. The results of the analysis state that partially Inflation has a significant negative effect on Stock Price Volatility while the BI Rate has a significant negative effect on Stock Price Volatility. Then the results of the simultaneous analysis state that inflation and the BI Rate have a significant effect on stock price volatility.
\end{abstract}

Keywords: Inflation, BI Rate, Stock Price Volatility

\section{INTRODUCTION}

At present the government is increasingly promoting socialization and education regarding "shares" to the public. Because participating in the ownership of shares of a company (issuer) means that the community has made investments that have automatically helped the government in increasing the nation's economic growth and development. Through the Financial Services Authority (OJK), socialization to the public is carried out by cooperating with several universities in Indonesia to provide an understanding to the public about what shares are, how to trade shares and what are the benefits. This socialization will automatically develop in the socialization of the capital market and what instruments are in the capital market. Collaborating with Universities as partners to socialize about shares because Higher Education interacts more intensely with the community through various Community Service activities as part of Higher Education Tridharma.

Higher Education can conduct socialization and education to the public not limited to one particular society, because basically those who can trade shares are all people, both the middle and lower and upper classes. How to own shares today which is relatively easy, 
making millennial generation who likes things that are fast and instant will be interested in trading stocks, because they can do it easily via CellPhone (HP). From the initial registration as an investor on the Indonesia Stock Exchange (IDX) everything is done online, and all information related to the company's stock price is updated, so that the Composite Stock Price Index (CSPI) information can be accessed easily through the RTI Business application. So the government is really serious about providing facilities and facilitating the community to own shares.

Owning shares now also does not require large funds, again the government makes it easy for prospective shareholders by stipulating that a minimum purchase of one lot $=100$ shares of shares. It is very different from the system before 2014, where potential investors who will buy shares of at least one lot $=500$ shares. Therefore, if the share price per share is $\mathrm{Rp}$. 100,000 , investors can buy shares by spending Rp. 10,000.

An easy and fast way of ownership of shares and a very affordable price, makes the government more optimistic that the Indonesian people will be more interested in owning shares and can trade shares online. With the increasing interest of the public to own shares, the investment will be even greater so that it will automatically support the country's economic growth.

For an investor who will buy shares, of course, need to pay attention to several things that can be taken into consideration in choosing stocks. There are two analytical techniques that can be used in selecting stocks, namely Technical analysis and Fundamental analysis. Technical analysis is done by taking into account the chart or the up and down trend of the company's stock prices which can now be accessed on the RTI Business application. While Fundamental analysis is done by analyzing the company's fundamental data, for example through financial statement data. Fundamental Analysis of course through several calculations to determine the Return (Revenue) and Risk of the company based on financial reports that have been published.

Stock prices are always fluctuating, sometimes up sometimes also down. Volatility (rise and fall) of the stock price for some investors is an art in stock trading because there is an opportunity to get capital gains (profits from buying and selling shares). Volatility of a company's stock price is influenced by several factors including internal and external factors of the company. Internal factors are factors that arise from within the company, while external factors are factors that come from outside the company.

In this study, two factors that influence stock price volatility are taken from external factors, namely the Inflation Value and the BI Rate. According to Mishkin (2008: 339) Inflation is a condition of a continuous increase in price levels. While the BI Rate or interest rate (interest rate) is the cost of loans or the price paid for loan funds (Mishkin, 2010: 4). The reasons for the selection of the two independent variables are the first, because in 2018 inflation is relatively stable and is in the category of mild inflation because it is under $10 \%$. The amount of inflation affects the purchasing power of the rupiah that has been invested, meaning that if inflation gets higher it can reduce the purchasing power of the rupiah. The second is the BI Rate which is the interest rate set by Bank Indonesia to maintain the inflation rate. Based on these two things, the researchers took the Value of Inflation and the BI Rate to be the variables that affect Stock Price Volatility.

The object of this research is PT. Unilever Indonesia Tbk. Reasons for choosing PT. Unilever Indonesia Tbk as the object of research is based on several considerations including because PT. Unilever Indonesia Tbk is one company that has gone public selling products that are consumed and used daily by the 
community. Then this company is also one of the companies in the Consumer Goods Industry sector on the Indonesia Stock Exchange (IDX) which has the highest share price among other similar companies. Based on this, the researchers took the object of research at PT. Unilever Indonesia Tbk.

Based on the things that have been explained above, the purpose of this study is:

1. To find out the effect of Inflation and the BI Rate partially on Stock Price Volatility at PT. Unilever Indonesia Tbk

2. To determine the effect of inflation and the BI Rate simultaneously on stock price volatility at PT. Unilever Indonesia Tbk

\section{RESEARCH METHODS}

\section{A. Research Type}

This type of research is quantitative research. Quantitative research is a type of research using quantitative data that is data in the form of numbers or data that can be converted into numbers, then analyzed using the appropriate analytical tools then described through comparative results (comparisons) about the similarities and differences from the results of the analysis that have been done. Everything is done to make it easier to draw conclusions.

\section{B. Research Design}

This research was conducted to find out how Influence of Inflation and BI Rate on Stock Price Volatility at PT. Unilever Indonesia Tbk. The data used in this study is secondary data, which is data that is obtained indirectly from the source, can be through an intermediary that can be justified. Secondary data can be in the form of a company's financial statements, company records, or it can also be in the form of accurate and unquestioned evidence. In this study the secondary data used are fluctuations in inflation values and the BI rate and share price volatility of PT. Unilever Indonesia Tbk from January 2018
- December 2018 accessed through the official website https://www.bi.go.id and https://www.idx.co.id. The secondary data will then be processed by researchers using Multiple Linear Analysis, and the results of the analysis will be interpreted so that a conclusion can be drawn.

\section{Data Collection Methods}

Researchers collected data taken from the official website https://www.bi.go.id and https://www.idx.co.id, aplication of RTI bssiness and Trading Activities in PT. Unilever Indonesia Tbk. Secondary data used in this study are the value of Inflation, BI Rate, and Stock Price Volatility at PT. Unilever Indonesia Tbk from January 2018 - December 2018.

\section{Types and Sources of Data}

The type of data in this study is secondary data that is data that is obtained indirectly from the source, can be through intermediaries that can be trusted and can be held accountable for the accuracy of the data. Secondary data for example is data in the form of company financial statements, important records belonging to the company, even in the form of accurate and unquestioned evidence. Secondary data in this study are the value of Inflation, BI Rate, and Stock Price Volatility at PT. Unilever Indonesia Tbk from January 2018 - December 2018.

In this study the data source is the official website https://www.bi.go.id and https://www.idx.co.id, aplication of RTI business and Trading Activities in PT. Unilever Indonesia Tbk.

\section{E. Definition of Variable Operations}

This study uses two independent variables (X1 and X2) and one dependent variable (Y). X1 is the Value of Inflation and $\mathrm{X} 2$ is the BI Rate while $\mathrm{Y}$ is the Stock Price Volatility at PT. Unilever Indonesia Tbk.

- Inflation (X1) is a condition where the amount of money in circulation is greater than the amount of goods. These 
conditions make the value of the currency small and less valuable. Inflation data used in this study is inflation data that occurred in January 2018 - December 2018. According to Bank Indonesia Inflation is the tendency of prices to increase in general and continuously.

- BI Rate (X2) is the interest rate set by Bank Indonesia as a policy to maintain a country's inflation. The BI Rate used in this study is Bank Indonesia interest rate data from January 2018 - December 2018.

- Stock price volatility is the rise in stock prices. Stock price volatility used in this study is stock price volatility at PT. Unilever Indonesia Tbk from January 2018 to December 2018.

\section{F. Data Analysis Methods}

\section{Classical Assumption Test:}

\section{a. Data Normality Test}

Normality Test is a test of normality of data distribution. The use of normality test is because in the parametric statistical analysis, the assumption that the data must have is that the data must be distributed in a normal manner. The purpose of normally distributed data is that the data will follow the form of a normal distribution. Normality test is useful to determine to determine data that has been collected normally distributed or taken from a normal population. The statistical method used in the data normality test is One Sample Kolmogorov Smirnov (Firdaus, 2019:211)

\section{b. Heteroscedasticity Test}

Heteroscedasticity test is used to find out whether or not there is a deviation from the classical assumption of heteroscedasticity., Namely the variance in residual variance for all observations in the regression model. Heteroscedasticity testing can be done with the Glesjer test, Spearman correlation test and park test (Firdaus, 2019:224).

\section{c. Multikolinearity Test}

Firdaus said

(2019:236)

Multicollinearity test is used to determine whether or not there is a deviation from the classic assumption of multicollinearity, namely the existence of a linear relationship between the independent variables in the regression model

Multicollinearity testing is done by looking at the value of Inflation Factor (VIF) in the regression model. Next compare the coefficient of individual determination $\left(r^{2}\right)$ with the value of determination simultaneously $\left(R^{2}\right)$

\section{Multiple Linear Regression Analysis}

Silalahi said (2010:430-431) Multiple linear regression analysis is a statistical technique that can be used to analyze the effect and relationship between one single dependent variable with several independent variables to use the value of the independent variables in predicting the value of the single dependent variable under study.

Meanwhile Firdaus said (2019:113) Multiple Regression Model (multiple regression model), which is a model where the dependent variable depends on two or more independent variables. The simplest multiple regression model is three-variable regression, which consists of one independent variable and two independent variables.

Furthermore, the multiple linear regression equation Inflation and the BI Rate on Stock Price Volatility at PT. Unilever Indonesia Tbk is as follows:

Information:

$$
\mathrm{Y}=a+b 1 \times 1+b 2 \times 2+e
$$

$\mathrm{Y}=$ Stock Price Volatility

$\mathrm{a}=$ constanta

b1 $=$ regression coefficient of inflation

b2 $=$ regression coefficient of BI Rate

$\mathrm{x} 1=$ Inflation

$\mathrm{x} 2=\mathrm{BI}$ Rate

$\mathrm{e}=$ residual factor 


\section{Analysis of the Coefficient of Determination}

Determination coefficient $\left(\mathrm{R}^{2}\right)$ aims to measure the ability of the model in explaining the variation of the dependent variable with a value between zero and one. If the value of $\mathrm{R}^{2}=0$ means the independent variable does not have the ability to explain the variation of the dependent variable and if the value of $R^{2}=$ 1 means the independent variable has the ability to explain the variation of the dependent variable. (Ginting MRM dan Sulasmiyati S, 2016).

Thus means that if $\mathrm{R} 2$ gets bigger or closer to 1 means that the independent variable is more able to explain the variation of the dependent variable.

\section{Hypothesis testing}

\section{a. $t$ Test (Partial Significance)}

The first hypothesis uses the $t$ test, Ghozali (2013:98) said if t test used to indicate the effect of partially independent variables on the dependent variable. The $t$ test uses several basic analyzes to determine the effect and relationship of variables in research. The decision to reject or accept $\mathrm{HO}$ is made by comparing the calculated $t$ value with the following formulation:

$$
\begin{aligned}
\text { Information: } \mathrm{t} & =\mathrm{t} \text { count } \\
\mathrm{bi} & =\text { regression weights } \\
\mathrm{Sbi} & =\begin{aligned}
\text { Standard deviation of the } \\
\end{aligned} \\
& \text { independent variable }
\end{aligned}
$$$$
t=\frac{b i}{S b i}
$$

The following basic analysis used in the $\mathrm{t}$ test are:

1. Comparing between tcount and ttable

If tcount $\leq$ ttable, then $\mathrm{H} 0$ is accepted and Ha is rejected.

If tcount $\geq$ ttable, then $\mathrm{H} 0$ is rejected and Ha is accepted.

2. Comparing the significance value with the real level.

If the significance value $\geq$ true significant (0.05) it means that $\mathrm{HO}$ is accepted and $\mathrm{Ha}$ is rejected.
If the significance value $\leq$ true significant (0.05) it means that $\mathrm{H} 0$ is rejected and $\mathrm{Ha}$ is accepted.

\section{b. F test (Simultan Significance )}

The $F$ test is used to see the significance of the effect of the independent variables simultaneously on the agreed upon variables ( Priyatno, 2010:144). In this study the F test was used to see the significance of the effect of the variables $\mathrm{X} 1, \mathrm{X} 2$ simultaneously on the $\mathrm{Y}$ variable.

$$
F=\frac{R^{2} /(k-1)}{\left(1-R^{2}\right) /(n-k)}
$$

Information:

$$
\begin{aligned}
& \mathrm{F}=\text { Testing simultaneously } \\
& \mathrm{R}^{2}=\text { Coefficient of determination } \\
& \mathrm{k}=\text { The number of variables } \\
& \mathrm{n}=\text { Number of observations } \\
& \text { (number of Samples) }
\end{aligned}
$$

Decision making criteria:

1. Compare the calculated $F$ value with $F$ table.

If $\mathrm{F}$ arithmetic $\leq \mathrm{F}$ table then $\mathrm{Ho}$ is accepted, meaning that simultaneously there is no effect of the independent variable on the dependent variable.

If $\mathrm{F}$ arithmetic $\geq \mathrm{F}$ table then Ho is rejected means that simultaneously there is an influence of the independent variable on the dependent variable.

2. Determine the level of significance. The expected significance level is $\alpha=5 \%$. This means that the expected error rate is $5 \%$ and the truth level is equal $95 \%$.

3. Comparing the significance value with the real level.

If the significance value nyata is significant $(0.05)$ it means that $\mathrm{HO}$ is accepted and $\mathrm{Ha}$ is rejected.

If the significance value nyata is significant $(0.05)$ it means that $\mathrm{H} 0$ is rejected and $\mathrm{Ha}$ is accepted.

\section{RESULT ANALYSIS}

PT. Unilever Indonesia Tbk as the object of this study, of course there are some things that lie behind it, first because 
PT. Unilever Indonesia Tbk is a company in the Consumer Goods Industry sector, where the sector is a sector that produces products that are consumed by people everyday so that the value of its shares is certainly more stable compared to companies from other sectors. Then the second, becausePT. Unilever Indonesia Tbk has the highest share price value among all companies in the Consumer Goods Industry sector on the Indonesia Stock Exchange (IDX). Both of these reasons are taken into consideration by researchers in selecting research objects. The variables used are inflation, BI Rate, and Stock Price Volatility. As for inflation data, BI Rate, and Stock Price Volatility of PT. Unilever Indonesia Tbk from January 2018 to December 2018 is as follows:

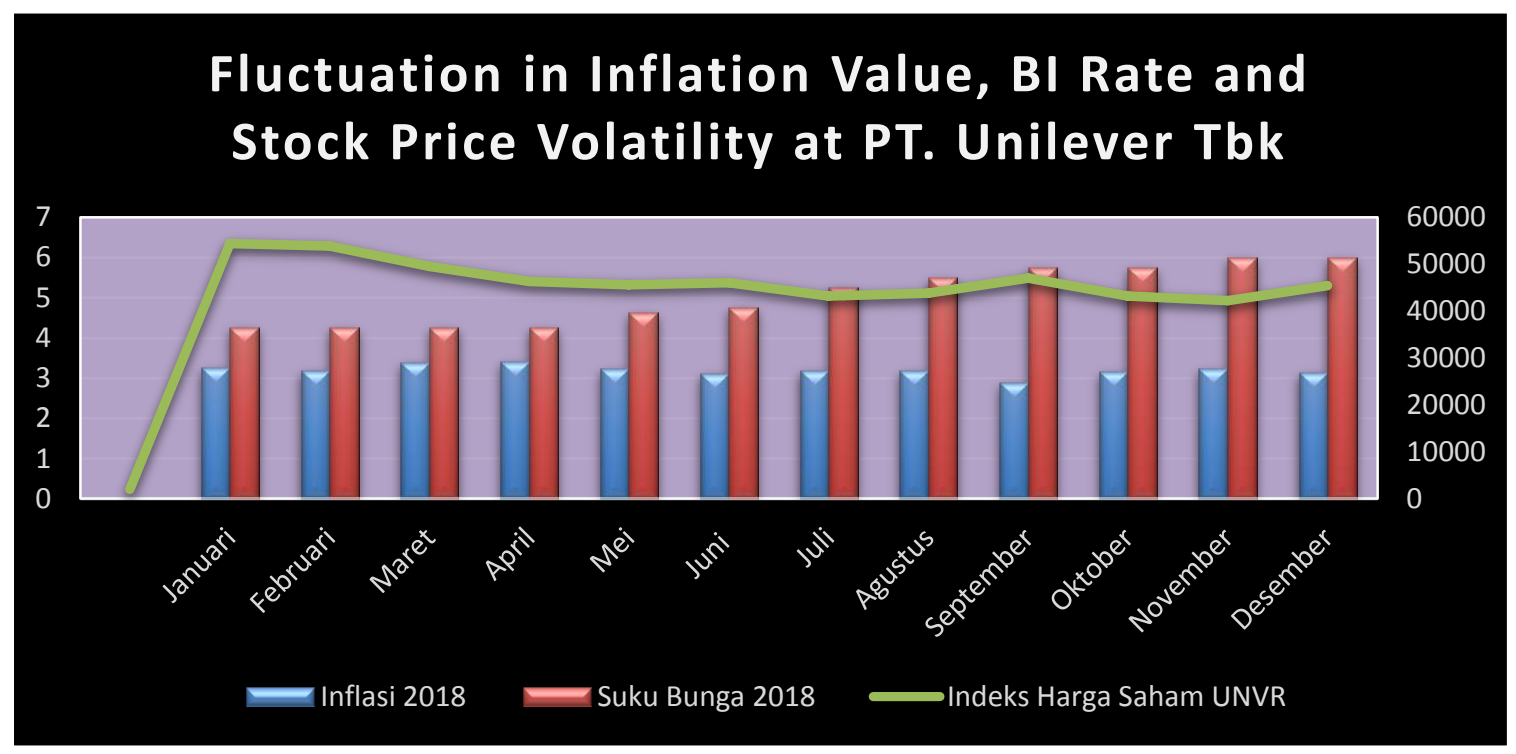

Figure 1. Fluctuation in Inflation Value, BI Rate and Stock Price Volatility at PT. Unilever Tbk Source : https://www.bi.go.id

Based on inflation data, BI Rate and Stock Price Volatility at PT. Unilever Indonesia Tbk above, researchers analyzed the data and obtained the following analysis results:

\section{Classic assumption test}

\section{a. Data Normality Test}

A data is said to be normal if the significance value (Asymp. Sig) is greater than $0.05(>0.05)$. If the significance value (Asymp. Sig) is less than $0.05(<0.05)$ then the data is not normally distributed.

Table 1. Data Normality Test Results

\begin{tabular}{|c|c|c|}
\hline & & $\begin{array}{c}\text { Unstandardized } \\
\text { Residual }\end{array}$ \\
\hline $\mathrm{N}$ & & 12 \\
\hline Normal & Mean & $0 \mathrm{E}-7$ \\
\hline Parameters & $\begin{array}{l}\text { Std. } \\
\text { Deviation }\end{array}$ & 1951,08202267 \\
\hline
\end{tabular}

\begin{tabular}{llr}
\hline & & $\begin{array}{c}\text { Unstandardized } \\
\text { Residual }\end{array}$ \\
\hline Most & Absolute &, 137 \\
Extreme & Positive &, 107 \\
Differences & Negative &,- 137 \\
Kolmogorov-Smirnov Z &, 474 \\
Asymp. Sig. (2-tailed) &, 978 \\
$\begin{array}{ll}\text { a. Test distribution is Normal. } \\
\text { b. Calculated from data. }\end{array}$ \\
\hline ree: Primary data processed
\end{tabular}

The results of the normality test above indicate that the influence of Inflation, the BI Rate, on Stock Price Volatility obtained a significance value (Asymp. Sig) of 0.978. This means that $0.978>0.05$, so it can be concluded that the data is normally distributed.

\section{b. Heteroscedasticity Test}

Regression that does not occur heteroscedasticity if 1) Data points spread above and below or around the number 0 , 
2) Data points do not collect only above or below it. 3) The distribution of data points may not form a wavy pattern then widened and widened again. 4) Distribution of patternless data points.

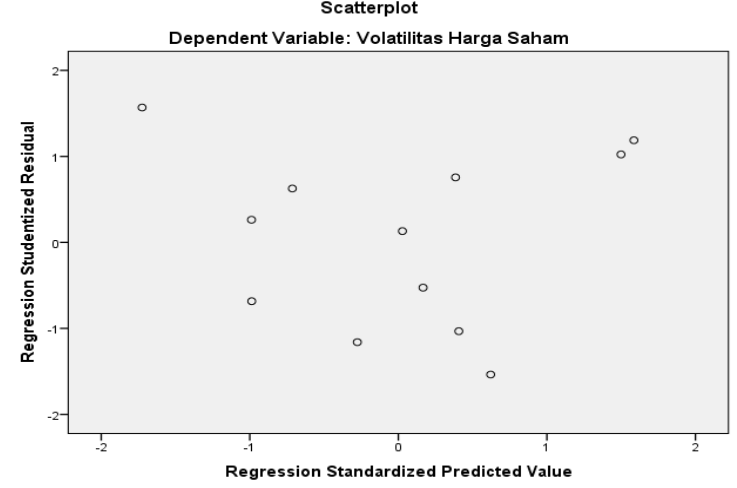

Figure 2. Heteroscedasticity Test

Heteroscedasticity test results above indicate that the points do not form a clear pattern. The points spread above and below zero on the $\mathrm{Y}$ axis, so it can be concluded that there are no symptoms of heteroscedasticity.

\section{c. Multicollinearity Test}

Multicollinearity test is used to see the value of Variance Inflation Factor. If the VIF value> 10 then multicollinearity occurs. However, if VIF $<10$, it is stated that multicollinearity does not occur.

Tabel 2. Multikolinearity test

\begin{tabular}{|c|c|c|c|}
\hline \multicolumn{4}{|c|}{ Coefficients $^{\mathrm{a}}$} \\
\hline \multirow{2}{*}{\multicolumn{2}{|c|}{ Model }} & \multicolumn{2}{|c|}{ Collinearity Statistics } \\
\hline & & Tolerance & VIF \\
\hline \multicolumn{4}{|c|}{ (Constant) } \\
\hline 1 & Inflasi & ,601 & 1,664 \\
\hline & BI Rate & ,309 & 3,232 \\
\hline \multicolumn{4}{|c|}{ a. Dependent Variable: Volatilitas Harga Saham } \\
\hline
\end{tabular}
Source: Primary data processed

Based on the Multicollinearity test results above, the value of Variance Inflation Factor (VIF) of each variable, namely Inflation of 1.664 and BI Rate of 3.232 smaller than $10(<10)$, so it can be concluded that between independent variables Multicollinearity does not occur

\section{Multiple Linear Regression Analysis}

Multiple Linear Regression Analysis is used to test hypotheses regarding: 1) Influence of Inflation and BI Rate partially on Stock Price Volatility, 2) Influence of Inflation and BI Rate simultaneously on Stock Price Volatility.

Table 3 Multiple Regression Analysis

\begin{tabular}{|c|c|c|c|c|}
\hline \multicolumn{5}{|c|}{ Coefficients $^{\mathrm{a}}$} \\
\hline \multirow{2}{*}{\multicolumn{2}{|c|}{ Model }} & \multicolumn{2}{|c|}{$\begin{array}{l}\text { Unstandardized } \\
\text { Coefficients }\end{array}$} & \multirow{2}{*}{$\begin{array}{c}\begin{array}{c}\text { Standardized } \\
\text { Coefficients }\end{array} \\
\text { Beta }\end{array}$} \\
\hline & & B & Std. Error & \\
\hline \multirow{4}{*}{1} & Constant & 112667,019 & 27757,383 & \\
\hline & Inflasi & $-12325,997$ & 7257,210 &,- 422 \\
\hline & BI Rate & $-5247,909$ & 1356,178 &,- 961 \\
\hline & Dependen & ariable: Vola & ilitas Harga $S$ & aham \\
\hline
\end{tabular}

Based on the results of the multiple regression analysis above, the relationship of Inflation, BI Rate to the Stock Price Volatility of PT. Unilever Indonesia Tbk can be realized in the following equation:

$\mathrm{Y}=112667,019--12325,997 \mathrm{X} 1-$ $5247,909 \times 2$

Based on the above equation, the constant value is 112667,019 which means that with the inflation and the BI Rate, the constant value of the Share price is 112667.019 .

Inflation variable regression coefficient of $-12325,997$ means that a $1 \%$ increase in the inflation variable assuming other variables are constant will cause a decrease in stock prices by $-12325,997$

BI Rate variable regression coefficient of $-5247,909$, meaning that a $1 \%$ increase in the BI Rate variable assuming other variables are constant will cause a decrease in stock prices by 5247,909

\section{Analysis of the Coefficient of Determination}

The basis used in the Determination Coefficient Analysis (R2) is the Adjusted $\mathrm{R} 2$ value. In this study these are shown in the following table: 


\begin{tabular}{|c|c|c|c|c|}
\hline \multicolumn{5}{|c|}{ Tabel 4. Model Summary ${ }^{b}$} \\
\hline Model & $\mathbf{R}$ & R Square & $\begin{array}{l}\text { Adjusted } \\
\text { R Square }\end{array}$ & $\begin{array}{l}\text { Std. Error of } \\
\text { the Estimate }\end{array}$ \\
\hline 1 &, $795^{\mathrm{a}}$ & ,632 &, 550 & 2672,83848 \\
\hline \multicolumn{5}{|c|}{$\begin{array}{l}\text { a. Predictors: (Constant), BI Rate, Inflasi } \\
\text { b. Dependent Variable: Volatilitas Harga Saham }\end{array}$} \\
\hline
\end{tabular}

Based on the data above Adjusted $\mathrm{R}$ Square of 0.550 or $55 \%$. This means that the influence of Inflation and BI Rate variables on Stock Price Volatility is $55 \%$, while $45 \%$ is influenced by other variables outside the study.

\section{Hypothesis testing}

a. $\mathbf{T}$ test. $\mathbf{T}$ test results in this study are as follows:

\begin{tabular}{lcr}
\multicolumn{3}{c}{ Tabel 4.5 } \\
\hline & Coefficients $^{\mathbf{a}}$ \\
& $\mathrm{t}$ & Sig. \\
Model & & \\
(Constant) & 4,059 &, 003 \\
Inflasi & $-1,698$ &, 124 \\
BI Rate & $-3,870$ &, 004 \\
a. Dependent Variable: Volatilitas Harga Saham \\
\hline
\end{tabular}

The $\mathrm{t}$-value of the Inflation variable is $-1,698$, this value is smaller than the table that is equal to 2.262 (tcount $<\mathrm{t}$ table). The significance level is 0.124 which means $>\alpha$ 0.05 . Thus it can be concluded that partially there is no significant effect between Inflation on Stock Price Volatility at PT. Unilever Indonesia Tbk.

The t-value of the BI Rate variable is $-3,870$, this value is greater than the table that is equal to 2.262 (tcount $>\mathrm{t}$-table). The significance level is 0.004 which means $<\alpha$ 0.05 . Thus it can be concluded that partially there is a significant influence between the BI Rate on Stock Price Volatility at PT. Unilever Indonesia Tbk.

b. Test $\mathbf{F}$. The results of the $\mathbf{F}$ test in this study are as follows:

Tabel 4.6 ANOVA

\begin{tabular}{lrrrrr}
\hline Model & Sum of Squares & df & Mean Square & F & Sig. \\
\hline Regression & 110186482,928 & 2 & 55093241,464 & 7,712 &, $011^{\text {b }}$ \\
Residual & 64296589,988 & 9 & 7144065,554 & & \\
Total & 174483072,917 & 11 & & & \\
a. Dependent Variable: Volatilitas Harga Saham & & & \\
b. Predictors: (Constant), BI Rate, Inflasi & & & \\
Source: Primary data processed
\end{tabular}

F-count is obtained at 7,712 and the number is greater than Ftable which is 4,26 (Fcount> Ftabe). The significance level is 0.011 , which means it is smaller than $\alpha$ 0.05 so it can be concluded that simultaneous inflation and the BI Rate have a significant effect on Stock Price Volatility at PT. Unilever Indonesia Tbk.

\section{INTERPRETATION}

\section{Influence of Inflation on Stock Price Volatility.}

Partial significance test results ( $\mathrm{t}$ test) Inflation on Stock Price Volatility states that Inflation has a significant negative effect on Stock Price Volatility. Negative signs indicate that inflation is inversely proportional to or contrary to Stock Price
Volatility, if Inflation goes up, the Stock Price will go down, and vice versa if Inflation goes down then the Stock Price will rise.

What needs to be underlined is that when this research was conducted (January 2018-December 2018) inflation was below $10 \%$ or included in the category of mild inflation so it is possible that when inflation is high, it may be that the results of the analysis will be different. In addition, given that PT. Unilever Indonesia Tbk is a Consumer Goods Industry sector company which produces products that are consumed or used daily by the public, so that inflation conditions especially inflation which is still in the category of mild inflation does not significantly affect the Stock Price. 
The results of this study are also in accordance with research conducted by Ginting, M. R. M., \& Sulasmiyati, S. (2016) which states that inflation does not have a significant negative effect on Stock Prices.

\section{Effect of BI Rate on Stock Price Volatility}

The results of the partial significance test (t test) of the BI Rate on Stock Price Volatility states that the BI Rate has a significant negative effect on Stock Price Volatility. A negative sign indicates that the BI Rate is inversely proportional to or contrary to Stock Price Volatility, if the BI Rate increases, the Stock Price will go down, and vice versa if the BI Rate goes down, the Stock Price will rise. This is in accordance with the theory of Tandelilin (2010: 104) which states that interest rates affect stock prices in reverse (cateris paribus)

Although the BI Rate and the Share Price are inversely proportional, the BI Rate has a significant effect on the Share Price. The partial significance test result of the BI Rate on Stock Price Volatility is different from the results of research by Ginting, M. R. M., \& Sulasmiyati, S. (2016) which states that the BI Rate has no significant negative effect on Stock Prices.

\section{Simultaneous Effect of Inflation and BI Rate on Stock Price Volatility}

Simultaneous significance test results (F test) states that inflation and the BI Rate have a significant effect on stock price volatility. In other words, the rise and fall of the share price is influenced by the micro condition of the issuer (company), it is also influenced by the macro factors of a country, this is supported by the results of the adjusted determination coefficient test (Adjusted R2) in this study which shows the results of $55 \%$. This means that it is true that inflation and the BI Rate as part of a country's macro factors significantly affect Stock Price Volatility.

\section{CONCLUSION}

This study analyzes the effect of inflation (X1) and BI Rate (X2) on stock price volatility as the dependent variable (Y) at PT. Unilever Indonesia Tbk. Data from the three variables are taken from January 2018 to December 2018. Based on the results of multiple linear regression analyzes that have been carried out it can be concluded that: 1)Through a partial significance test ( $\mathrm{t}$ test), it is stated that inflation has no significant effect on stock price volatility. While the BI Rate has a significant effect on Stock Price Volatility. 2)Through the simultaneous significance test (F test) it is stated that Inflation and the BI Rate have a significant effect on Stock Price Volatility.

\section{IMPLICATIONS}

There are several macroeconomic factors other than inflation and the BI Rate that affect Stock Price Volatility, for that in subsequent studies can add other macroeconomic factors such as Currency Exchange Rates, World Oil Prices and so forth. For prospective investors who will invest their capital to buy shares, it is necessary to pay attention to macroeconomic factors that affect Stock Price Volatility. To get the maximum research results, further research should use inflation data when inflation is at a moderate or high inflation position. For PT. Unilever Indonesia Tbk needs to always maintain that the Stock Price remains stable, so that potential investors to buy shares of the company.

\section{REFERENCES}

Firdaus, Muhammad. 2019. Ekonometrika Suatu Pendekatan Aplikatif. Jakarta: Bumi Aksara

Mishkin, F.S. 2008. Ekonomi Uang, Perbankan, dan Pasar Keuangan. Edisi 8. Buku 2. Jakarta: Salemba Empat.

Mishkin, F.S. 2010. Ekonomi Uang, Perbankan, dan Pasar Keuangan. Edisi 8. Buku 1. Jakarta: Salemba Empat. 
Silalahi, Ulber. 2010. Metode Penelitian Sosial. Bandung: PT Refika Aditama.

Sugiyono. 2007. Statistika Untuk Penelitian. Bandung: CV. Alfabeta

Ghozali, Imam. 2013. Aplikasi Analisis Multivariate dengan Program IBM SPSS 21. Edisi 7. Semarang: Badan Penerbit Universitas Diponegoro.

Ginting, M. R. M., \& Sulasmiyati, S. (2016). Pengaruh Tingkat Suku Bunga, Nilai Tukar Dan Inflasi
Terhadap Harga Saham (Studi Pada Sub-Sektor Perbankan Di Bursa Efek Indonesia Periode 2011-2015). Jurnal Administrasi Bisnis, 35(2), 77-85.

Priyatno. 2010. Analisis Statistik Data Dengan SPSS.Yogyakarta: Media Komunikasi

Tandelilin, Eduardus. 2010. Portofolio dan Investasi Teori dan Aplikasi: Edisi Pertama. Yogyakarta: Kanisius 